\title{
Studies on the Production of Gasoline from Heavy oil (furnace oil) by Thermal Cracking
}

\author{
M. S. Jamala, Mohammad Ismail ${ }^{b *}$, M. Yunus Miahª, M. Naimul Haque ${ }^{a}$, Sujit Kumar Banik \\ ${ }^{a}$ Institute of Fuel Research and Development, Bangladesh Council of Scientific and Industrial Research (BCSIR), \\ Dhaka -1205, Bangladesh and ${ }^{b}$ Department of Applied Chemistry and Chemical Technology, University of \\ Dhaka, Dhaka-1000, Bangladesh.
}

\begin{abstract}
Heavy fuel oil (furnace oil) was thermally cracked by thermal cracker under different parametric conditions such as cracking temperature, molar ratio of heavy oil to diesel and cracking time to optimize the yield of the final product. In this thermal cracking process, the yield was gradually increased with the increase in temperature and time. After a certain temperature and time no significant increase in yield was observed. Thermo gravimetric analysis (TGA) was done to observe the percentage of weight loss with increasing temperature. The obtained cracked oil was fractionated by atmospheric vacuum distillation unit. Products obtained from different experiments under different conditions showed almost similar physico-chemical properties. Optimization was done on the basis of yield (\%wt). The optimum yield (56.2\%) of light petroleum fraction (gasoline) was obtained under the following experimental conditions: cracking temperature: $445^{\mathrm{O}} \mathrm{C}$; molar ratio of furnace oil to diesel 95:05; and cracking time: $30 \mathrm{~min}$. The properties such as density, water content, ash content, pour point, flash point, viscosity, range of boiling point, sulphur content, carbon residue, octane number etc. of the obtained light petroleum fraction were found almost similar to that of the commercial grade gasoline.
\end{abstract}

Key words: Furnace oil, Thermal cracking, Gasoline, Thermo gravimetric analysis.

\section{Introduction}

The demand of fuel oil is increasing day by day in Bangladesh as well as all over the world. In the last century with the increase of the use of gasoline in automobiles, emphasis was given for the production of gasoline and diesel instead of heavy oil and kerosene and this made the introduction of thermal cracking process. With thermal cracking, the make-up of residual fuel oils (Furnace oil) changed markedly and light petroleum fraction can be obtained from the furnace oil (Albert and Ralph, 1960). Since the demand for high value petroleum products such as middle distillate gasoline is increasing day by day, so maximizing of liquid product yield from various processes and valorization residues (furnace oil) each of immediate attention to refiners. At the same time environmental concern has increased, resulting in more rigorous specifications for petroleum products including furnace oil. These trends have emphasized the importance of processes that convert the heavier oil fractions into lighter and more valuable clean product (Gray 1994). Besides thermal cracking, a number of technology have been developed over the years for furnace oil upgrading which include

\footnotetext{
* Corresponding author, E-mail: mismailacct@gmail.com
}

process that are based on the carbon rejection and hydrogen addition routes (Speight, 1994; Le Page et. al. 1992). Some processes are solvent deasphalting, residue fluid catalytic cracking, hydro processing etc.

In Bangladesh, a huge quantity of furnace oil is produced from the processing of crude petroleum by Eastern Refinery limited (The only crude petroleum processing industry in Bangladesh) that has a cheaper market price. Though this oil is using in boiler, furnace and other purposes but it creates a great disposal problem and pollutes the environment.

The aim of the present investigation is to produce light petroleum fraction from furnace oil through thermal cracking process for meeting high demand of gasoline, proper utilization of furnace oil and saving of foreign exchange.

\section{Materials and Methods}

\section{Raw materials}

Furnace oil and diesel (commercial grade) were the main raw materials. Furnace oil and diesel were collected from 
local market. The physico-chemical characteristics of furnace oil are given below:

\begin{tabular}{|l|c|c|}
\hline Name of the properties & Method & Result \\
\hline Density, (Kg/L) & ASTM D 1298 & 0.9624 \\
Viscosity at $100^{\mathrm{O}} \mathrm{C}, \mathrm{cSt}$ & ASTM D 445-65 & 96.68 \\
Pour point, ${ }^{\mathrm{C} C}$ & ASTM D 97-57 & 0.0 \\
Water content, (v/v)\% & IP- 74/57 & 10 \\
Carbon residue, (wt/wt)\% & ASTM D 189-65 & 16.61 \\
Ash content, (\%) & ASTM D 482-63 & 0.0235 \\
\hline
\end{tabular}

Further extensive information on the properties of residual fuel oil or furnace oil can be obtained in the literature (Gray 1994; Speight 1994; Bartholomew et. al. 1994 and Quann et. al. 1988).

Fig. 1 represents typical thermo gravimetric curve for heavy fuel oil. From the TGA data, it can be said that the wt. loss up to $15 \%$ at temperature range of $180^{\circ} \mathrm{C}$ may be attributing to the light petroleum fraction content. It also concluded that up to $80 \%$ wt loss take palace at $332{ }^{\circ} \mathrm{C}$ indicates heavy oil also content some diesel and kerosene fraction.
Diesel oil is used to dilute the stiff form of furnace oil. Besides this, diesel oil speed up the molecular reaction in cracking and give more amount of light petroleum fractions. At the end of the cracking, diesel is obtained as product around twice of the initial amount that is mixed with furnace oil. The physico-chemical characteristics of commercial diesel oil are given below:

\begin{tabular}{|l|c|c|}
\hline Name of the properties & Method & Result \\
\hline Density, Kg/L & IP-160/57 & 0.8445 \\
Kinematic Viscosity, 70 ${ }^{\circ}$ F cSt & ASTM D 445-65 & 6.06 \\
Flash point, ${ }^{\circ} \mathrm{C}$ & ASTM D 93-62 & 70 \\
Pour point, ${ }^{\mathrm{O} C}$ & ASTM D 97-57 & -2 \\
Water content, (v/v)\% & IP- 74/57 & Zero \\
Residue on evaporation, wt \% & IP-131/58 & 0.43 \\
Cetane no. & ASTM D 613 - 86 & 51 \\
\hline
\end{tabular}

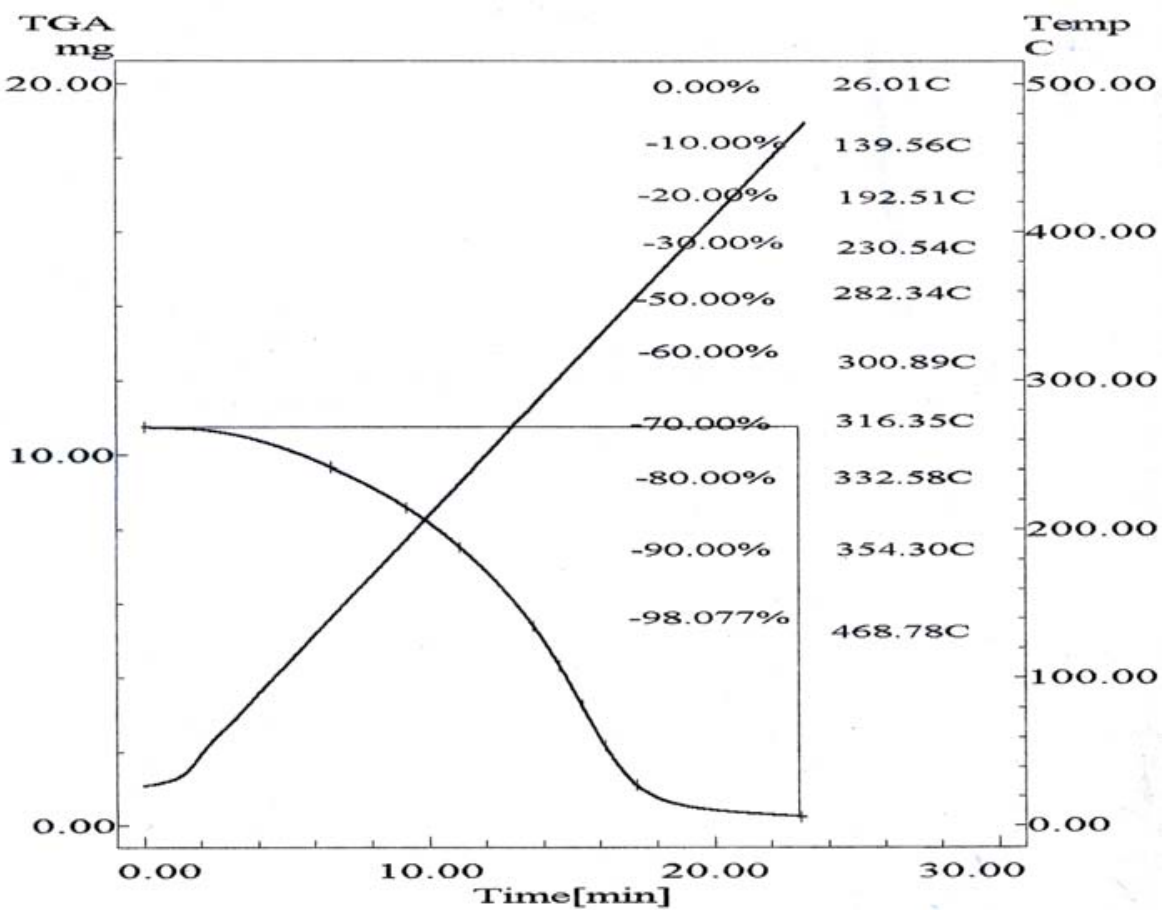

Fig. 1. Thermo gravimetric curve of heavy fuel oil (Furnace oil) 


\section{Experimental Method}

There are several steps involved in the thermal cracking process of furnace oil.

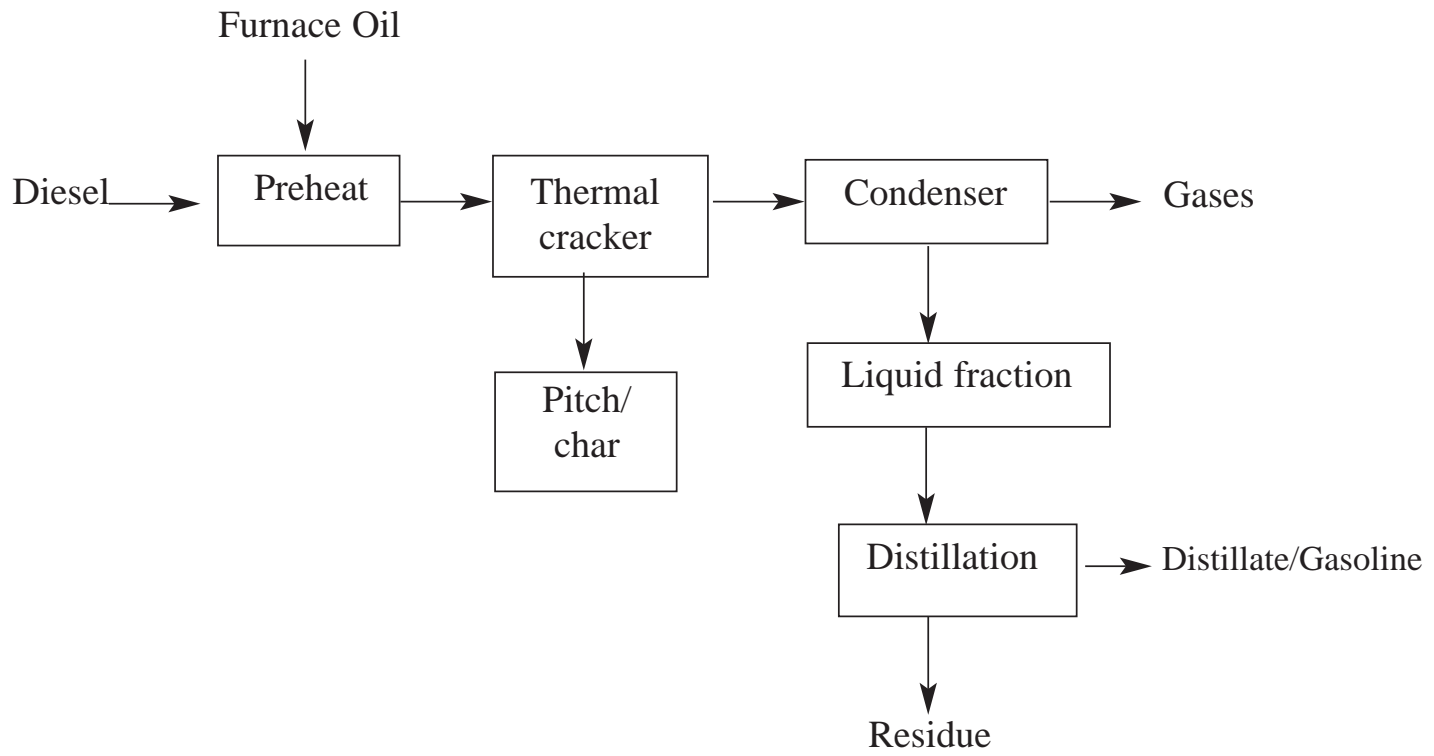

of the collected light fractions were also analyzed by ICP_OES (Inductive Coupled Plasma _Optical Emission Spectrophotometer).

Fig. 2. Overall flow sheet for production of light petroleum fraction from furnace oil

The furnace oil was first pre-heated at $105^{\mathrm{O}} \mathrm{C}$ to remove water. Thermal cracking was carried out in a thermal cracker. Cost consideration of catalyst use \& its regeneration in catalytic cracking led the research team to carry out thermal cracking of furnace oil. In future, there is a scope to comparative study of thermal and catalytic cracking of furnace oil with diesel. Cracking was done in batch process. The mixture of furnace oil and diesel were taken into the reactor of the cracker. Heater surrounds the reactor. There is a nozzle in the upper side of the reactor, which is connected with a condenser. No pressure is applied from out side. Since cracking was carried out in closed vessel reactor, an internal pressure of around 1000-1300 psi was formed due to heating.

In condenser, the light petroleum fractions obtained by cracking were condensed. Uncondensed gaseous products were passing through a gas flow meter and collected for further investigation. The condensed liquid products were subjected to atmospheric vacuum distillation unit to separate the light petroleum fraction. The distillate (up to $180{ }^{\circ} \mathrm{C}$ ) was collected as light petroleum fractions whose physico-chemical properties were determined by standard methods to compare with that of commercial gasoline. The gravimetric analysis of furnace oil, cracked residue and light fraction was carried out by TGA (TGA-50, Shimadzu). Heavy metals

\section{Results and Discussion}

Thermal cracking of furnace oil was done at different molar ratio of furnace oil and diesel, temperature and cracking time to optimize the yield. First the molar ratio of furnace oil is optimized at constant temperature and cracking time (Table I). Then the cracking temperature of furnace oil was optimized at constant molar ratio and cracking time (Table II). Lastly, the cracking time of furnace oil was optimized at constant temperature and molar ratio (Table III). The thermogravimetric analysis (TGA) results of furnace oil and light petroleum fraction (Gasoline) are shown in Fig 1 and Fig 2. TGA indicates the weight loss of any substance with increase of temperature.

\section{Optimization of molar ratio}

In case of molar ratio optimization, the molar ratio of furnace oil to diesel varies from 100:0 to 75:25 by maintaining cracking temperature at $435^{\circ} \mathrm{C}$ and cracking time of $30 \mathrm{~min}$ (Table I). The optimum molar ratio of furnace oil to diesel was found 95:05.

\section{Optimization of cracking temperature}

For optimization of cracking temperature, the temperature changes from $415^{\mathrm{O}} \mathrm{C}$ to $460{ }^{\mathrm{O}} \mathrm{C}$ by maintaining molar ratio 
Table I. Experimental results for optimization of molar ratio

\begin{tabular}{|c|c|c|c|c|c|}
\hline Sl. no & Cracking Time & Cracking Temperature & $\begin{array}{c}\text { Molar ratio } \\
\text { (Raw material : Diesel) }\end{array}$ & $\begin{array}{c}\text { Distilled } \\
\text { product, gm }\end{array}$ & $\%$ of yield \\
\hline 1 & \multirow{6}{*}{$30 \min$} & \multirow{6}{*}{$435^{\mathrm{O}} \mathrm{C}$} & $100: 0$ & 40.9 & 40.9 \\
\hline & & & $95: 05$ & 52.5 & 52.5 \\
\hline 3 & & & $90: 10$ & 49.8 & 49.8 \\
\hline 4 & & & $85: 15$ & 45.2 & 45.2 \\
\hline 5 & & & $80: 20$ & 44.6 & 44.6 \\
\hline 6 & & & $75: 25$ & 46.9 & 46.9 \\
\hline
\end{tabular}

Table II. Experimental results for optimization of cracking temperature

\begin{tabular}{l|c|c|c|c|c}
\hline Sl. no & $\begin{array}{c}\text { Molar ratio } \\
\text { (Raw material: diesel) }\end{array}$ & Cracking time & Cracking temperature & Distilled product & \% of yield \\
\hline 1 & & & $415^{\circ} \mathrm{C}$ & 36.5 & 36.5 \\
2 & & $425{ }^{\circ} \mathrm{C}$ & 39.2 & 39.2 \\
3 & $95: 05$ & $30 \mathrm{~min}$ & $435{ }^{\circ} \mathrm{C}$ & 52.5 & 52.5 \\
4 & & & $445{ }^{\circ} \mathrm{C}$ & 56.2 & 56.2 \\
5 & & $455{ }^{\circ} \mathrm{C}$ & 57.5 & 57.5 \\
6 & & $460^{\circ} \mathrm{C}$ & 58.1 & 58.1 \\
\hline
\end{tabular}

Table III. Experimental results for optimization of cracking time.

\begin{tabular}{l|c|c|c|c|c}
\hline Sl. no & $\begin{array}{c}\text { Molar ratio } \\
\text { (Raw material: Diesel) }\end{array}$ & Cracking temperature & Cracking time & Distilled product & \% of yield \\
\hline 1 & & & $20 \mathrm{~min}$ & 49.7 & 49.7 \\
2 & & & $25 \mathrm{~min}$ & 52.3 & 52.3 \\
3 & & & $30 \mathrm{~min}$ & 56.2 & 56.2 \\
4 & & $445{ }^{\circ} \mathrm{C}$ & $35 \mathrm{~min}$ & 57.5 & 57.5 \\
5 & & & $40 \mathrm{~min}$ & 58.9 & 58.9 \\
6 & & & $50 \mathrm{~min}$ & 59.8 & 59.8 \\
\hline
\end{tabular}

Table IV. Characterizations of the obtained light gasoline:

\begin{tabular}{l|c|c|c}
\hline Name of the analysis & Method & \multicolumn{2}{|c}{ Result } \\
\cline { 3 - 4 } & & Processed gasoline & Commercial gasoline \\
\hline Boiling range, ${ }^{\circ} \mathrm{C}$ & ASTM D 1160 & $25-180$ & $19.8-196$ \\
Density, Kg/L & ASTM D 1298 & 0.756 & 0.7423 \\
Viscosity at 40 ${ }^{\circ} \mathrm{C}, \mathrm{cSt}$ & ASTM D 445-65 & 0.725 & 0.760 \\
Octane number, $^{\circ}$ & ASTM D 2699 & 81.0 & 83 \\
Pour point, ${ }^{\circ} \mathrm{C}$ & ASTM D 97-57 & 0.20 & $>-20$ \\
Water content, \% $^{\text {Carbon residue, \% }}$ & IP- 74/57 & 0.037 & 0.00 \\
Ash content, \% & ASTM D 189-65 & 0.05 & 0.023 \\
Acid value, mg KOH/g & ASTM D 482-63 & 0.03 & 0.07 \\
Sulphur content, \% & IP- 1/58 & 0.39 & 0.09 \\
\hline
\end{tabular}


95:05 and cracking time 30 min (Table II). The optimum temperature was found at $445^{\circ} \mathrm{C}$

\section{Optimization of cracking time}

To determine the optimum cracking time, time ranges from 20 to $50 \mathrm{~min}$. by maintaining constant temperature of $445^{\circ} \mathrm{C}$ and molar ratio of furnace oil to diesel at 95:05 (Table III). Optimum cracking time was found at $30 \mathrm{~min}$.

\section{Product characterization}

From Table IV, it was seen that the physico-chemical properties of the light fractions obtained from furnace oil are almost similar to that of commercial grade gasoline, which are available in the market. Fig. 2 showed the thermo gravimetric curve for light petroleum fraction (Gasoline) obtained from thermal cracking of heavy oil. From the graph it is found that the initial boiling point of the product is about $26.07^{\mathrm{O}} \mathrm{C}, 10 \% \mathrm{wt}$. loss of the product takes place at $79.47^{\circ} \mathrm{C}, 50 \%$ wt. loss takes place at $131.22^{\circ} \mathrm{C}$ and weight loss up to $98 \%$ takes place at the temperature range of $173^{\mathrm{O}} \mathrm{C}$. This trend of weight loss of the obtained gasoline is almost similar to that of commercial gasoline. The analysis results in Table $\mathrm{V}$ revealed that the product contains trace amount of heavy metals (in ppm) that is within the acceptable limit.

TableV. Heavy metal analysis in obtained light gasoline

\begin{tabular}{l|c|c|c}
\hline $\begin{array}{l}\text { Name of the } \\
\text { heavy metals }\end{array}$ & $\begin{array}{c}\text { Distilled } \\
\text { product }\end{array}$ & $\begin{array}{c}\text { Distilled } \\
\text { residue }\end{array}$ & $\begin{array}{c}\text { Cracked } \\
\text { residue }\end{array}$ \\
\hline Arsenic (As) & ND & 2.0 & 0.95 \\
Barium (Ba) & 0.05 & 0.65 & 0.2 \\
Cadmium (Cd) & ND & ND & ND \\
Chromium (Cr) & 2.0 & 0.5 & 0.25 \\
Mercury (Hg) & ND & ND & ND \\
Lead (Pb) & 2.0 & 7.0 & 4.35 \\
Antimony (Sb) & 0.2 & 2.5 & ND \\
Selenium (Se) & ND & 7.0 & 1.5 \\
\hline
\end{tabular}

* ND $=$ Not Detectable

Besides the light petroleum fraction, cracked residue (during cracking), distilled residue (during distillation) and some amounts of gas are produced in the different stages of experiment, which are needed to further investigation.

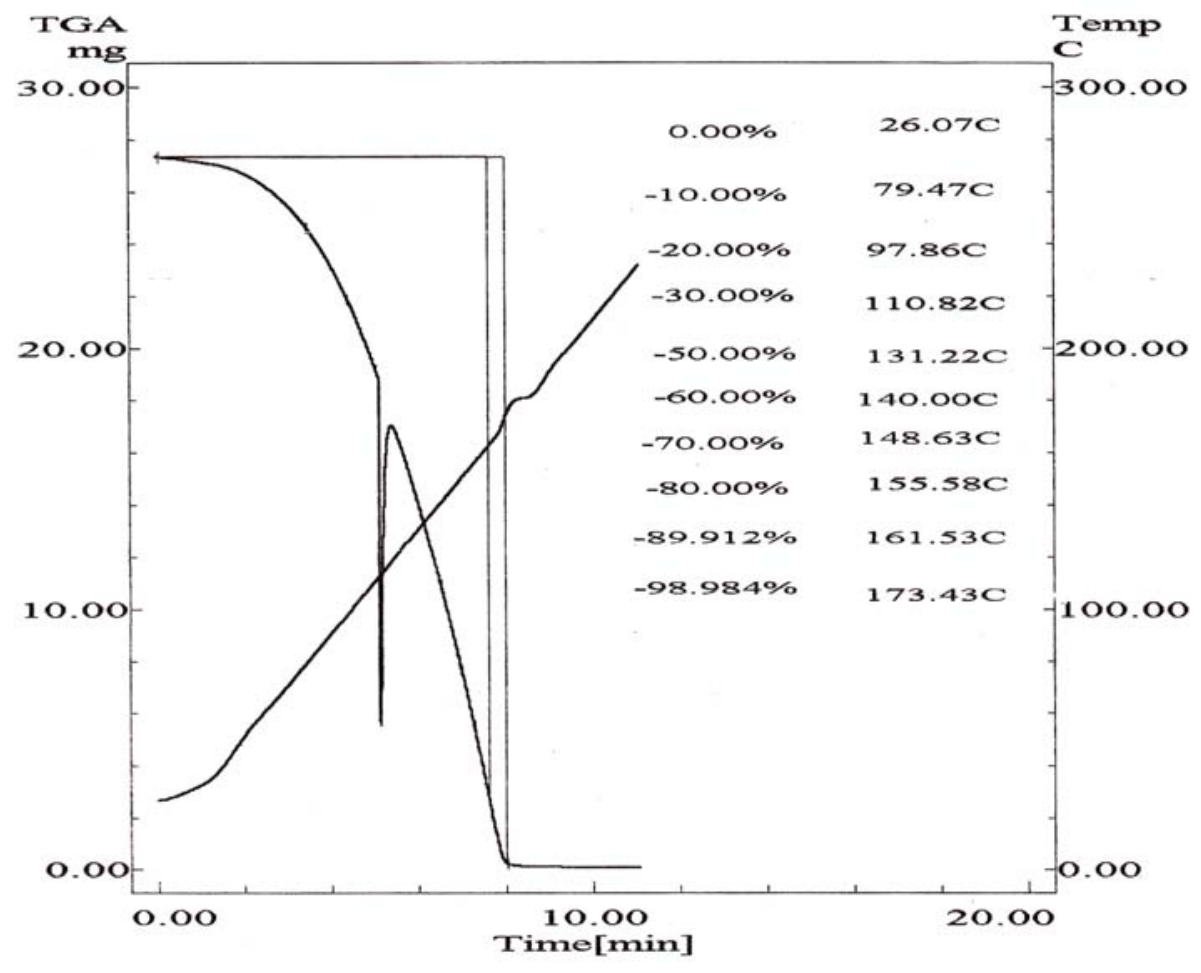

Fig. 2. Thermo-gravimetric curve of obtained gasoline fraction 
The over all material balance for process is as follows:

\begin{tabular}{l|c|c|c|c|c}
\hline \multicolumn{2}{|c|}{ Input } & \multicolumn{2}{c}{ Output } \\
\hline Name & Mass & Percentage & Name & Mass & Percentage \\
\hline Furnace oil & $190 \mathrm{~g}$ & $95 \%$ & Distilled product (Gasoline) & $112.4 \mathrm{~g}$ & $56.2 \%$ \\
\cline { 3 - 5 } & & & Diesel & $18.90 \mathrm{~g}$ & $9.45 \%$ \\
\hline Diesel oil & $10 \mathrm{~g}$ & $5.0 \%$ & $\begin{array}{c}\text { Cracked residue } \\
\text { and gas evolved }\end{array}$ & $62.70 \mathrm{~g}$ & $31.35 \%$ \\
\cline { 3 - 5 } & & & Experimental loss & $1.60 \mathrm{~g}$ & $0.8 \%$ \\
\hline Total & $200 \mathrm{~g}$ & $100 \%$ & Total & $200 \mathrm{~g}$ & $100 \%$ \\
\hline
\end{tabular}

From the economic point of view in Bangladesh, the cost of one-liter furnace oil is 30 taka and that of one-liter commercial diesel oil is 44 taka, whereas the cost of one liter of commercial Gasoline is 78 taka (Source: BPC). Besides gasoline and diesel fraction, some residue and char products are also obtained from cracking Cost estimation of raw materials, products, investment \& operation and break-event point analysis shows the positive response in economical viability of the conversion of furnace oil to gasoline.

\section{Conclusion}

The overall optimum condition for the thermal cracking of the furnace oil was at molar ratio of furnace to diesel 95:05, temperature $445^{\circ} \mathrm{C}$ and time $30 \mathrm{~min}$. In this condition, the yield was 56.2\%. Physico-chemical properties such as density, water content, pour point, octane number, carbon residue, ash content, sulphur content etc. of commercial grade gasoline and processed fuel revealed that they possessed almost similar properties. Heavy metal contents of the products were within the acceptable limit. Thus, this investigation will help in meeting high demand of gasoline and thereby saving foreign exchange.

\section{References}

Albert. O. S. and Sant Ralph W. V (1960), Residual fuel oils. Petroleum Products Handbook- by Virgil B. Guthrie, 1st edn, Mcgraw-Hill book company, New york, Sec. 8-1.

Bartholomew C. H., Oballa M. C. and Shih S. S. (1994), Catalytic hydro processing of petroleum and distillate. New York: Marcel Dekker.
Gray M. R. (1994), Upgradation petroleum residues and heavy oils, New York: Marcel Dekker.

Le Page L. F., Chatila S. G and Davidson M. (1992) Resid and heavy oil proc. Paris: Eds. Technip

Quann R. J., Ware R. A., Hung and Wei. C. H. (1988) J. Adv Chem Eng; 14: 95.

Rana M. S., Samano V., Ancheyata J.and Diaz J. A. I. (2007) A review of recent advances on process technologies for up gradation of heavy oil and residua, Fuel 86: 1216-1231.

Speight J. G (1994) The Chemistry and Technology of Petroleum. NY: Marcel Dekker;

Received : July 09, 2008;

Accepted : February 23, 2009 